\title{
Special Issue | Upper Cenozoic stratigraphy of the southern North Sea and Baltic basins
}

\section{Introduction}

Coastal low-lands are densely populated areas characterized by large economic activity. The shallow subsurface plays an important role because of geotechnical requirements for the foundation of structures and its potential for natural resources, such as sand, gravel, and groundwater. The application of geoscientific data requires that the subsurface is represented as 2D and 3D models displaying the stratigraphic relations of sedimentary rock units, both on-and off-shore.

From 8 - 11 April 2003, we organized an international workshop on 'Integrated Land-Sea Lithostratigraphic Correlation' at the Netherlands Institute of Applied Geoscience TNO in Utrecht, the Netherlands. This Special Issue on 'Upper Cenozoic stratigraphy of the southern North Sea and Baltic basins' contains papers presented at the workshop. The aim of the workshop was to discuss existing stratigraphic models and approaches applied by geoscience groups in countries bordering the North Sea and Baltic basins. This volume includes studies of seismic data and data from outcrops and boreholes. Depending on the position within the basin and the subbottom depth of the target strata, different data acquisition techniques and stratigraphic tools are used. Mutual understanding of stratigraphic correlation techniques between workers studying different parts of a basin is essential for land-sea correlations of strata to be successful. This volume provides an overview of the stratigraphic correlation methods in use by the different workers and their application.

In non-marine basin margin settings, boreholes and outcrops are studied. Initial sediment classification is generally geared towards lithostratigraphic approaches. Stratigraphic correlation is produced by bed to bed correlation in laterally extensive successions. However, hiatuses are generally numerous on basin margins. Pollen analyses aid in environmental reconstruction. Radiocarbon and luminescence dating are useful in the Upper Pleistocene portions of non-marine successions. In the present volume, Ber, Hamblin et al., and McMillan et al., discuss correlation methods and their limitations in the Neogene/Quaternary stratigraphy on land. Ber addresses this problem discussing absolute dating combined with biostratigraphic and chemostratigraphic correlations of interglacial beds situated between glacial tills in Poland. In contrast, Hamblin et al. study the glacial beds and provide a reinterpretation of the glacial till stratigraphy at Norfolk, England, based on till provenance and bed to bed correlation.

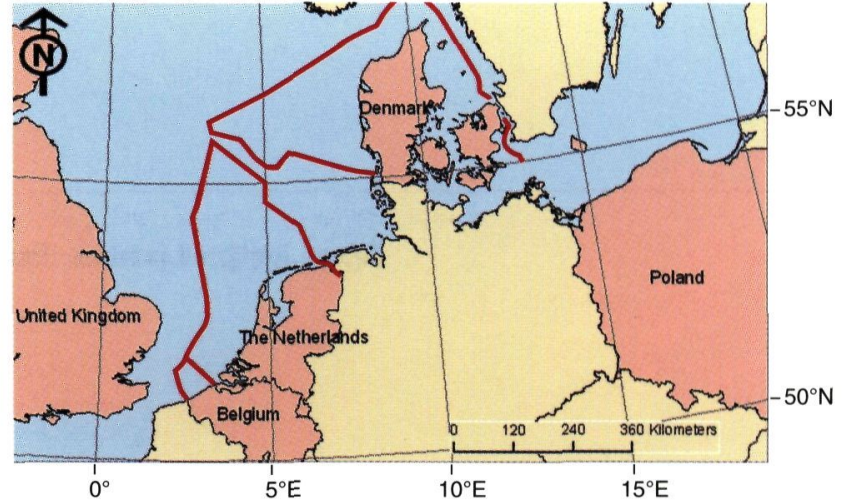

Fig. 1. The Upper Cenozoic stratigraphies of Great Britain, Belgium, the Netherlands, Denmark and Poland are discussed in this Special Issue, including the continental shelf portions of Belgium, the Netherlands and Denmark. Contributing countries are indicated by pink shade and if marine data is included their territorial waters are outlined in red.

McMillan et al. provide an overview of the Neogene and Quaternary lithostratigraphy onshore in Great Britain.

In the marine realm, seismic data is used and seismolithostratigraphy combined with biostratigraphic approaches form the basis of the stratigraphic models. Towards the center of a basin sedimentary successions are generally more continuous, which facilitates the use of sequence stratigraphic and allostratigraphic methodologies. From a marine perspective, Konradi, Larsen and Andersen, and Rijsdijk et al., provide concise review papers of the Upper Cenozoic stratigraphy in the Danish and Dutch sectors of the North Sea Basin. The authors use an integrated approach including aspects of lithostratigraphy, biostratigraphy, seismostratigraphy and allostratigraphy to correlate units over large distances and across land-sea boundaries. Finally, LeBot et al. review the Cenozoic stratigraphy in Belgium with an on-shore to off-shore correlation and its application in the construction of windmill farms off-shore.

This Special Issue demonstrates the full range of stratigraphic correlation techniques that are applied along the borders of the North Sea and Baltic basins. We hope that this volume will lead to a next workshop where stratigraphic correlations will be extended beyond national boundaries. The development of an international stratigraphic model facilitates exchange of knowledge and provokes innovative approaches to tackle the geo-scientific issues of densely populated coastal areas.

Sandra Passchier, Kenneth Rijsdijk, Cees Laban 